Vol. 1, No. 1: DOI:

\title{
RISKY BUSINESS: BUILDING A SUPER LUXURY WINE BRAND
}

\author{
Lindsey M. Higgins, Jean Dodson Peterson, and Michael H. Lau \\ California Polytechnic State University \\ San Luis Obispo (CA)
}

$\mathrm{T}$ hree months before, in early January 2016, Ethan had been so committed to the idea of a price change that he had convinced everyone-except the winemaker-that it was the right thing to do. Ethan had the support of the sales staff, wine club/ tasting room manager, and marketing team; however, he did not have the support of Andrew Anderson, ARA Estates' winemaker. Andrew was opposed and said, “This is risky. I don't see how you can justify it. I know you guys understand the market better than I do, but I believe it will put a huge financial risk on the winery if it doesn't work. I don't know if I can agree with the decision.”

Ethan Dorsey, the Managing CEO, thought, "In eleven years of working with Andrew, this is the first time he has voiced a serious concern over one of my ideas. Together we've grown ARA into a highly respected winery, among the best in Napa—so I have to take Andrew seriously.”

Ethan hoped a price increase (from USD 55 to USD 75/bottle) would elevate the prestige of ARA Estates' Accession wine in the minds of consumers, with minimal impact on wine club sales. Accession was the most recognizable of ARA Estates' wines and was valued among highend wine consumers. Raising the price could increase its luxury brand image as well as increase revenue for ARA. Ethan knew there would be negative feedback from some wine club members, but the Accession label was distributed throughout the U.S. in multiple retail outlets, and, after talking to his distributors, he felt confident that increased retail sales would more than account for any decreased club sales.

After barrel and bottle aging, the time had come to release the 2013 wines. Wine club members needed to be introduced to the nearly 50 percent price increase Ethan had planned for the 2013 Accession label (scheduled to be released at the April 2016 release party). In addition, Accession consumers would be faced with tighter availability of the 2013 vintage. Because of the higher quality of the 2013 vintage, more production was allocated to ARA's higher-end wines resulting 
in decreased production for the Accession label (from 6,500 cases to 4,000 cases); re-allocation between labels was common practice in the wine industry.

Ethan wondered,

How will the wine club members react to the price increase and the restricted production? I am relying on Paul [Paul Teel, the tasting room and wine club manager] to do an excellent job of promoting the Accession label because he has a clear understanding of club members. However, will club members buy less and hurt sales? Will they recognize Accession's move to become a higher luxury brand?

ARA's sales team and distributors had expressed confidence to Ethan that they could sell Accession at the higher price, but he wondered if the packaging changes and price increases he had initiated were enough to position the Accession label higher in the super premium luxury wine category. Ethan knew that if he was going to back off the strategy, which was what Andrew thought he should do, he needed to do it before the release party and the launch of the redesigned label for Accession. Andrew argued that they would lose their customer base, but Ethan felt that by increasing Accession's price per bottle, upscaling Accession's packaging, elevating its wine list standing, and reducing the number of cases available would lead to increased demand. He thought, "I believe that lost consumers because of the adjustment in price will be offset by national sales, along with increases in wine club and tasting room revenues. However, if I move forward with this new pricing strategy, as Andrew pointed out, ARA incurs a huge financial risk if consumers fail to accept the elevation of Accession to a higher-end luxury label as opposed to the "entry level" Napa Cabernet it has been."

\section{WINE INDUSTRY BACKGROUND}

Wines in the U.S. were often categorized into nine different price segments based on price per $750 \mathrm{ml}$ bottle (see Exhibit 1). Although attractive to many wine producers, the high end (luxury, super luxury, and icon wines) made up a relatively small portion of the U.S. wine market. However, many of these top-tier wines were from the Napa Valley. Wines in the luxury, super luxury, and icon categories were typically targeted toward affluent, middle-aged wine consumers. High spenders on wine were more involved wine consumers that had higher levels of wine knowledge and placed a high-level of importance on their wine purchase decision.

Higgins L. M. et al. / Wine Business Case Research Journal 1 (1) 2016 


\section{Exhibit 1}

\section{Price Segments in the U.S. Wine Market}

\begin{tabular}{|l|c|}
\hline \multicolumn{1}{|c|}{ Segment } & Price Range (USD) \\
\hline Jug wines & $<3$ \\
\hline Fighting varietals & $3-7$ \\
\hline Popular premium & $7-10$ \\
\hline Mid-premium & $10-14$ \\
\hline Ultra premium & $14-25$ \\
\hline Luxury & $25-50$ \\
\hline Super luxury & $50-100$ \\
\hline Icon & $>100$ \\
\hline
\end{tabular}

Source: Cholette and Castaldi (2005). Analyzing the US Retail Wine Market Using Price and Consumer Segmentation Models (Refereed), available online: http://academyofwinebusiness.com/wp- content/uploads/2010/05/AnalyzingUSRetail.pdf

To be successful in the super luxury and icon categories, it took more than high-quality wine. Consumers also looked for aging ability and the wine's reputation before they invested in a bottle of wine. Successful luxury wine brands were those that found the right balance of product quality, a keen understanding of marketing, and a focus on detail. It was common for super luxury and icon wines to be marketed as exclusive, scarce products, with the use of status imagery during promotion. Sincerity and authenticity, shown through a passion for wine production, relationship to place, and the rejection of commercial motives were recognized as keys to marketing a luxury wine brand. ${ }^{1}$ Research has suggested that the buying process for luxury wines was significantly different than the buying process for everyday wines. As an experiential product, the purchase of a new wine was risky. That risk was amplified when the cost per bottle of wine to consumers was so high. Consumers who purchased in the super luxury and icon categories typically spent more time in the advanced planning stage and researched the wine before making a purchase.

Consumers frequently used price as a signal for quality, yet buying based on price was not foolproof. Given the branded nature of their product, wine producers could set their prices. Research had shown that premiums were embedded into wine prices depending on the region, quality ratings, and label designations. In one study, wines that included the term "estate wines" were shown to be priced seven percent higher than vineyard designate wines and six percent higher than "reserve" wines. ${ }^{2}$ Additionally, research had shown that there was a positive

${ }^{1}$ Beverland, M. B. (2005). Crafting brand authenticity: the case of luxury wines. Journal of management studies, 42(5), 1003-1029.

${ }^{2}$ Estate is a term used to describe wine made from grapes that are grown on land owned by the winery. A vineyard designate wine is one that is almost entirely made from grapes grown in that vineyard. To be labeled as a wine from a specific vineyard, US law requires $95 \%$ of the fruit comes from that vineyard. Reserve is a term used to indicate that the wine is of higher quality than usual. Reserve wines are often held on to, rather than sold immediately, and command a premium. 
correlation between expert scores and wine prices. In fact, each point increase on a 100-point tasting scale was estimated to be worthy of a five percent increase in the wine's price. ${ }^{3}$ However beyond quality and marketing, the winery's reputation was shown to be one of the biggest factors in consistently explaining wine prices. Nevertheless, wine pricing was still believed to be largely imperfect, with many opportunities for consumers to find good bargains (high-quality wines for a lower than expected price) as well as wines with poor value (high prices with a lower than expected quality).

\section{NAPA VALLEY}

Napa Valley was considered one of the premier wine-growing regions in the world since 1970s and had wine history dating back to 1858 when the first commercial vineyard was planted. Because of its ideal climate and soil makeup (terroir), Napa Valley produced some of the world's top wines. These wines were mainly Bordeaux varietal driven.

According to The Wine Institute, California was home to more than 4,000 bonded wineries in 2014, with 400 of those wineries in the Napa Valley. The Napa Valley region was divided into two distinct growing areas, mountain and valley floor, which offered two distinct growing climates. There were sixteen-registered American Viticultural Areas (AVA) in the region. ${ }^{4}$ In the valley, Oakville, Stags Leap District, and Rutherford were the better-known AVAs. Mountain regions included Mount Veeder, Howell Mountain, Diamond Mountain, and Spring Mountain AVAs. There were more than 40 wineries in the Howell Mountain AVA (Exhibit 2). Although consumers had a vast number of wine choices available to them, the competition among mountain wineries was much narrower. Outstanding reviews of another winery's Howell Mountain Cabernet drew new attention and new consumers to the region; however, those reviews also pulled some of the regular ARA Estates consumers away from its wines to the better-or more recently well-reviewed wine.

\footnotetext{
${ }^{3}$ Schroeter, C., Ritchie, J. L., \& Rickard, B. J. (2011). Factors that influence prices for cool climate wines: a hedonic analysis of the market for Riesling. Journal of Agribusiness, 29(1), 105.

${ }^{4}$ AVAs in the U.S. are federally recognized grape growing regions. For wine to be labeled with a specific AVA, at least $85 \%$ of the grapes must have been grown within that AVA.
} 
Exhibit 2

Howell Mountain Wineries

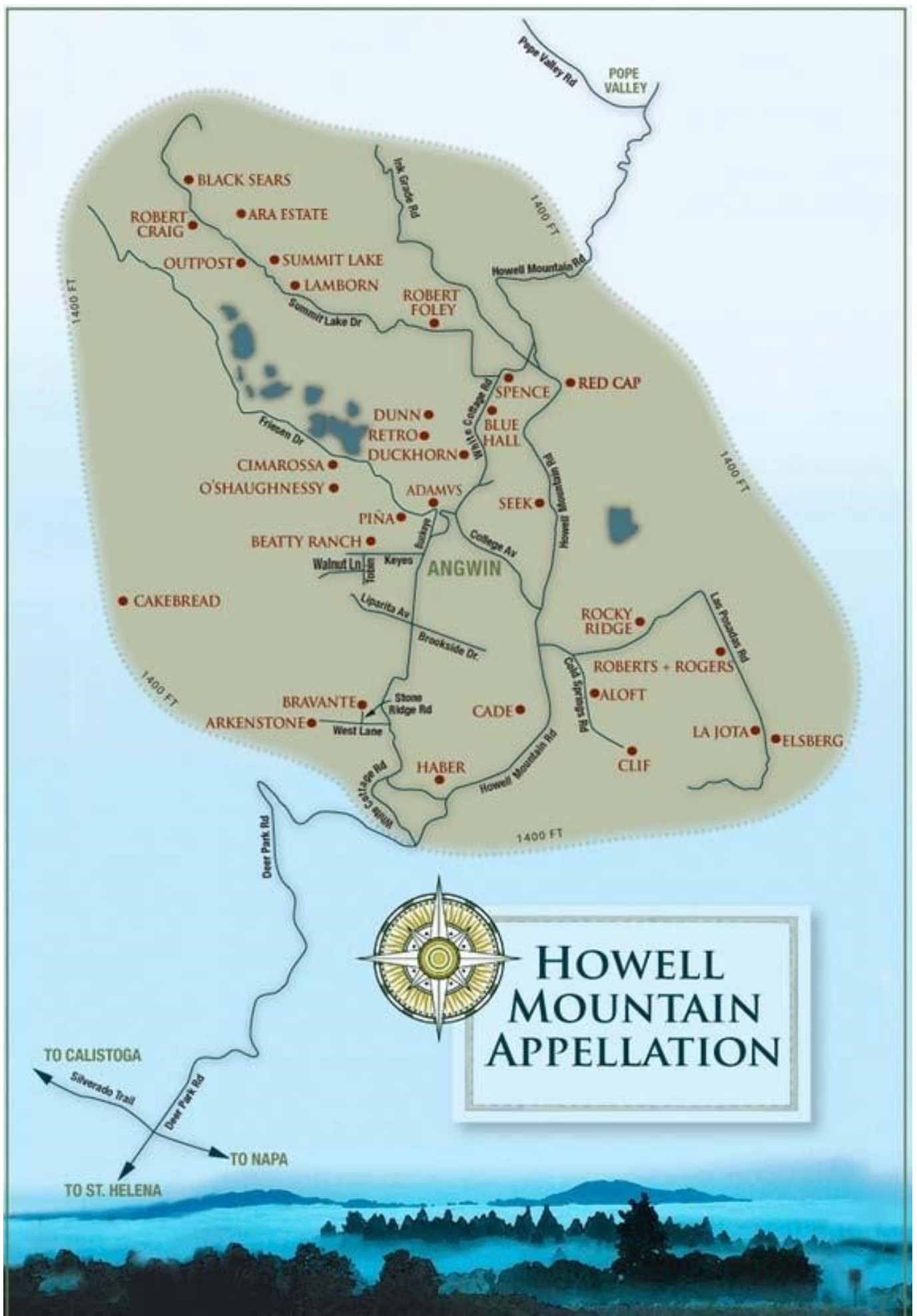

Source: http://.www.howellmountain.org 
Retail wines from Napa Valley were priced mainly in the luxury segment and higher (greater than USD 25/bottle) regardless of AVA origin. As a result of the quality and brand recognition for well-known Napa Valley vineyards and wineries, wines from this area often commanded a premium with top wines past the USD 100/bottle price point. These icon and super luxury wines were mainly purchased by established wine consumers. Supply and demand greatly influenced wine prices. Producers also took into consideration grape prices, which ranged from USD 10,000/ton and USD 30,000/ton for Napa Valley grapes. At those prices, the cost of juice in a bottle of wine was between USD 21 and USD 62. This was compared to grape prices of USD 300/ton in other regions of California (less than USD 0.50/bottle). Top Napa Valley AVAs such as Oakville and Rutherford commanded the highest prices for grapes.

\section{NAPA VALLEY MOUNTAIN WINERIES}

Mountain wines in Napa Valley were recognized as being distinctly different from their valley floor counterparts. In general, valley floor wines were bigger and more fruit forward while mountain wines were more structured, concentrated, and age-worthy. Mountain vineyards avoided the majority of the ocean fog, which often settled among the valley floor vineyards. Avoiding the fog layer allowed for more direct sunlight on the developing berries. The increased altitude also translated to more even temperatures compared to the valley floor vineyards. Evening temperatures were warmer, and daytime temperatures were traditionally cooler for mountain vineyards compared to those at lower altitudes. Despite increased rainfall on the mountain, the volcanic soils dried quickly due to their porous nature, preventing moisture accumulation and excess vine growth. Better drainage typically translated to fruit with complex flavor profiles. Compared to valley wines, mountain wines were driven by a more mineral and herbal flavor. These differences came from the soil quality and temperature. Howell Mountain AVA was at elevations between 1,400 feet and 2,200 feet and was sometimes up to $15^{\circ} \mathrm{F}$ cooler than the valley floor.

The quality of mountain wines was considered equal to valley floor wines, yet unique due to the flavor profile differences. Well-known mountain wineries such as Dunn, Outpost, Summit Lake and Robert Foley all commanded a premium for their top wines equal to many valley floor counterparts that were over the USD 100/bottle icon-price point. Mountain wines below the USD 100/bottle price point were still considered a good value from top producers when compared to equally sized and recognized valley floor counterparts at a higher price point.

\section{COMPETITION AMONG MOUNTAIN WINERIES}

Throughout the early 2000s, an expansion of mountain focused wine producers in Napa Valley occurred, increasing ARA Estates' competition. ARA's most direct competitor, Suh Winery (established in 1998), marketed a Napa Valley Cabernet Sauvignon blend, labeled Elevation. Elevation was priced at USD 60 for the 2010 and 2011 vintages and later increased to USD 70 for the 2012 vintage. Suh Winery's Elevation label was listed in the 2010 and 2011 Wine 
Spectator Editor's Pick Guide and was described as "The gateway to the Napa Valley cult wine industry - A leader in the next generation of Cabernet.”

In addition to Suh Winery and ARA Estates, wine consumers faced an ever-growing selection of elite mountain wines from Napa, each of which was working to have its entry level Cabernets (USD 50 - USD 60/bottle price range) serve as a stylistic and financial stepping stone for consumers, moving them away from traditional bold valley floor Cabernets to the more delicate mountain blends. Producers hoped consumers would move toward the more expensive mountain wines that rounded out the most elite wines in each winery's portfolio.

Although other Cabernets from Howell Mountain ranged in price from USD 75/bottle for the 2012 Red Cap Vineyards to USD 200/bottle for Robert Foley’s Howell Mountain Cabernet, Ethan considered the new Accession pricing strategy reasonable given that several other Howell Mountain wineries' introductory Cabernet Sauvignon blends were priced around USD 60/bottle and traditionally scored in the mid to low 90s on a national scale (see Exhibit 2 for comparable neighboring Howell Mountain AVA wineries). Additionally, Ethan justified the price increase because 2012 Napa Valley wines experienced a 4.4 percent price increase and a 3.4 percent increase in volume. The average price for a bottle of Napa Valley Cabernet Sauvignon rose to USD 78.61 in 2012 while the average bottle price for a Napa Valley red blend reached USD 88.52. ${ }^{5}$

\section{ARA BACKGROUND}

\section{The Early Years of ARA Estates}

Shawn Lincoln founded ARA Estates Winery in 1990. When Shawn first arrived in Napa Valley in the early 1980s, he headed to the Howell Mountain District AVA situated in California's Vaca Mountain Range (see Exhibit 3). Over the next three decades, Shawn learned to appreciate the uniqueness of mountain grown fruit compared to the traditional valley floor production of Napa Valley.

\footnotetext{
${ }^{5}$ Wines \& Vines, 2012, 2012 Direct to Consumer Wine Shipping Report. Ship Compliant and Wines \& Vines. Available at: http://www.winesandvines.com/pdf/2013Direct-to-ConsumerShipping-Report.pdf
} 


\section{Exhibit 3}

Howell Mountain AVA

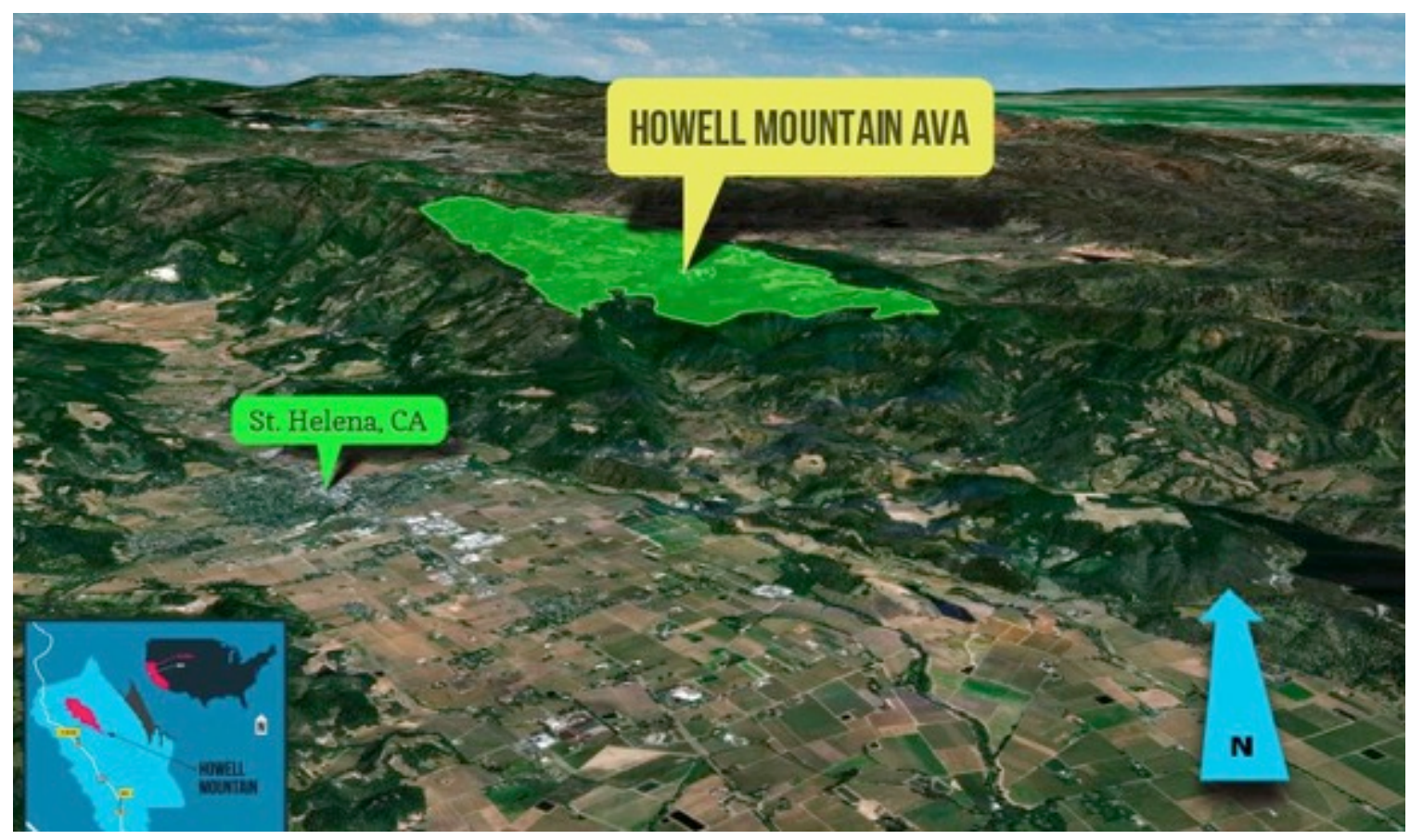

Source: http://.www.winefolly.com

Despite Shawn's interest in mountain wines and the initial success of his introductory label, Accession (a Napa Valley red blend), he also experimented with other varietals from all over California including an Amador County Zinfandel and a Central Coast Syrah. This lack of focus in a viticultural area, wines produced, and style caused a major issue with brand identity and overall quality during the early years. By 2004, ARA Estates was in financial trouble with a backlog of unsold wine and had no real marketing plan apart from tasting room sales (see Appendix 1 for a history of key ARA events). After a great deal of thought, Shawn retired as acting CEO and moved into a figurehead position. He brought in a new Managing CEO, Ethan Dorsey, and a new winemaker, Andrew Anderson. Ethan had successfully managed multiple wineries over his 18-year career and had previously worked in wine distribution. Andrew, with 14 years experience in high-end boutique production wineries in Sonoma, was a seasoned winemaker before he joined the ARA Estates team. In 2007, ARA hired Paul Teel to manage their wine club and tasting room. Paul successfully built and managed the club to nearly 2,000 members.

\section{Refining and Developing Focus}

To create brand identity and address excess inventory, Ethan pulled all the cases of non-Napa Valley production out of distribution in 2005, leaving only the Accession red blend available for purchase. In conjunction with the newly appointed winemaker, in 2006, a consulting winemaker 
was brought in to review the historical wines produced at ARA Estates Winery and to envision the direction the brand should go to set it apart. It was quickly decided that ARA Estates Winery would return to its roots and focus on becoming a Cabernet Sauvignon house with a focus on mountain wines, particularly Howell Mountain. Focusing on mountain wines was the key factor that helped set ARA Estates Winery apart from other Napa Valley price-point competitors (ARA's original positioning).

The refocus resulted in the need to evaluate the vineyards from which fruit was being sourced and to consider retaining new contracts with mountain vineyards that met the quality and stylistic requirements of the new brand. By 2007, vineyard contracts with premium mountain producers were in place and ARA Estates Winery produced three Cabernet Sauvignon wines, each from a unique mountain AVA: Mount Veeder, Howell Mountain, and Spring Mountain. Because of its previous success and positive brand association, the Accession red blend label was continued from the early ARA Estates Winery portfolio. With the 2007 vintage (released in spring 2010), the wines from the mountain AVAs accounted for approximately 8,500 of the 15,000 cases ARA Estates produced, with the Accession red blend making up the other 6,500 cases. The year 2007 also marked a significant business transition as Ethan evolved the brand from a family dynamic to a true business model when he hired Paul Teel, plus a national sales director, a controller, a director of the wine club, and a retail sales director. His strategy expanded sales beyond the tasting room and into nationwide restaurant sales. The personnel expansion was a vital component in the restructuring of the winery and the elevation of the brand to a national scale. Paul Teel helped grow and stabilize the wine club membership and tasting room sales programs into a very successful direct-to-consumer (DTC) channel.

The DTC channel was highly regarded in the wine industry as it brought the highest margin. Wines were sold to consumers at full retail price. Although distribution offered significantly broader access to consumers and the potential for higher volume sales, wines were sold to a distributor at a wholesale price (typically 50 percent of retail price). Partially due to the three-tier distribution laws in the U.S., distributors had to be used to reach restaurants and retail wine markets. ${ }^{6}$

\section{ARA's Direct-to-Consumer Sales}

Though ARA's wine club had been acquiring new members, many members had been with them since the early 1990s and were passionate supporters of its wines. With a growth of about 5 percent each year, ARA Estates' wine club hit 1,800 members at the time of the 2012 release. Consumers joined ARA's wine club not only for the 20 percent discount on most of its wines, but also for the first chance to buy newly released wines, exclusive wines, and the member

\footnotetext{
${ }^{6}$ After the repeal of prohibition, laws were enacted regarding the sale and distribution of alcoholic beverages. Producers (tier 1 ) were required to sell wine through a licensed wholesale distributor (tier 2) who then sold the wine to retailers (tier 3) and consumers bought the wine from retailers.
} 
parties. Members tended to be educated and experienced wine drinkers familiar with Cabernet Sauvignon mountain production. As advocates for the brand, wine club members would frequently bring friends into the tasting room and were a lucrative source of new wine club members.

Wine clubs were typically monitored for three key metrics: club conversion rates (how often do tasting room visitors become wine club members), attrition rates (members who leave the club during a particular period), and incremental sales (spending by club members in addition to their membership shipments). Within the Napa Valley, a two percent conversion rate was considered above average. Paul was always happy to boast about ARA's conversion rate of nearly 3.5 percent since 2012. Napa Valley saw a 22 percent attrition rate in 2014, and, while ARA's attrition rate was around 14 percent, there was a part of Paul that was concerned about a change in strategy that might result in much higher attrition rates for ARA. And, although ARA's club had been growing (at around 5 percent per year), wineries in the Napa Valley had a net wine club growth of 16 percent in 2014. The increase in wine club memberships in the Napa Valley (and across the country) was attributed to consumers becoming increasingly interested in wine as well as wineries improving their ability to connect with consumers, among other things. ${ }^{7}$

ARA Estates' visitors tended to be rather outspoken, and many were very active in online wine forums. Ethan had the tasting room staff regularly watch for posts on ARA Estates wines online. In general, the comments were positive and centered around Accession's outstanding quality-toprice ratio (QPR). The following quote is an example of the type of feedback posted online regarding ARA Estates Winery:

On our most recent visit to Napa and on the advice of a friend back home in San Diego, we stopped by the ARA Estates Winery tasting room. What a find! These mountain cabs were knockyour-socks-off good. In particular, both my wife and I fell in love with their Accession label (we came home with a case). What a superb value this wine is. Thank you, ARA Estates... we will be back.

\section{Facing New Challenges}

Ethan, who constantly looked for ways to improve the business model and wine quality, explored the possibility of moving from mainly non-estate grown (contract purchased) fruit to estateowned vineyards and dropping production from 6,500 to 4,000 cases. Switching to estate-owned vineyards for the Accession label required the purchase of approximately 24 acres. Estate-grown wines tended to have a higher marketable value. This move would reduce net fruit production costs by 10 percent a year but would require hiring a vineyard management company. The fruit cost per bottle would decrease to USD 15.75/bottle from USD 17.31/bottle, creating an

\footnotetext{
${ }^{7}$ Wine Business Monthly, 2015. July 2015. Available at: http://www.winebusiness.com/wbm/?go=getDigitalIssue\&issueId=7695\&dataId=152615\&recen $\underline{\text { tArticleRedirect }=\text { true }}$
} 
additional USD 1.56/bottle in margin and the opportunity to market the label as being estate produced. In 2010, ARA Estates actively pursued vineyard properties located on each of the mountain designates; however, at the time, only one small vineyard was purchased. Cost and availability had limited ARA's ability to purchase additional vineyards.

In the six years after Ethan had taken over as Managing CEO, the business became financially stable and evolved into a more traditional business model with limited ties to the founder. The winery became one of the most respected Cabernet Sauvignon houses in Napa Valley, especially among the mountain-designate producers. Unfortunately, in 2011, the growing conditions were challenging, and quality across the region was compromised. The cold and wet conditions of spring caused a reduction in berry set. The cool summer temperatures followed by rains proceeding and during harvest created mold issues. To minimize the infection and spread of powdery mildew and the Botrytis fungus, harvest took place before optimal berry maturity was reached. These conditions resulted in concern over the planned evolution of the ARA Estates Winery brand. The 2014 release of the 2011 vintage came on the heels of the economic recession that affected sales of many luxury goods, including wine. Furthermore, the price of grapes in 2012 increased as a result of lower than expected yields in 2011. However, the 2012 vintage and 2013 vintage were expected to be of excellent quality from good growing conditions.

\section{Accession Brand}

The Accession label was one of the initial wines produced by ARA Estates Winery in 1990. The word 'accession' referred to the act of joining or adding to. Naming ARA Estates' initial label Accession was intended to be a nod to ARA Estates joining the ranks of other brands in this prestigious winegrowing region. It was legally classified as a Napa Valley red wine blend because, although the majority of the fruit came from Shawn Lincoln's personal vineyard property, some of it was a collective of the excess mountain fruit that traditionally went into the other mountain designate labels. Initially, the Accession label accounted for about 3,500 cases and was considered the introductory tier of the ARA Estates Winery brand. Prior to the restructuring of the business, Accession sold for USD 35/bottle (the 1990 to 2001 vintages). Shortly after Ethan's hire, he instituted a small increase in price to USD 40/bottle for the 2005 release of the 2002 vintage. Ethan adjusted the price to account for Accession being the only label available for sale from ARA Estates at the time. When the 2006 Accession vintage was released in spring of 2009, it received a score of 94 from Robert Parker and the Wine Advocate. In response to the favorable review on the 2006 vintage, the price for the 2007 vintage released in spring of 2010 was increased to USD 50. The 2007 vintage managed to top the previous review with a score of 97 from Robert Parker and the Wine Advocate. Two consecutive high scoring vintages justified the price per bottle increase to USD 55 for the 2008 vintage, released in 2011. In 2012, Accession (2008 vintage) was poured by the glass at the French Laundry, a

Higgins L. M. et al. / Wine Business Case Research Journal 1 (1) 2016 
three-star Michelin restaurant in Napa Valley. ${ }^{8}$ Over time and with the gain in popularity, Accession production had risen to over 6,500 cases by the release of the 2009 vintage in 2012.

\section{Sales Channels}

Normal distribution channels for ARA Estates Winery (including Accession) had focused on DTC (tasting room and wine club) sales until additional marketing staff was hired in 2007. By 2013, sales distribution of all ARA Estates Winery brands were partitioned with 25 percent of sales to restaurants, 20 percent through the tasting room, 30 percent through wine club purchases, and 25 percent to specialty wine shops (see Exhibit 5). Although they spanned the country, the restaurants that carried ARA Estates' wine were mainly fine-dining restaurants with well-developed wine lists. Ethan hoped that, with the repositioning of the Accession label and with the help of its distributors, restaurant sales would be elevated. Additionally, he hoped to encourage wine club enrollment from new customers. Increasing sales to restaurants and through the wine club would mean a reduction in distribution to specialty wine shops.

Exhibit 5

Accession Sales and Prices by Distribution Channel

\begin{tabular}{|l|c|c|c|c|}
\hline & Restaurants & $\begin{array}{c}\text { Specialty Wine } \\
\text { Shops }\end{array}$ & $\begin{array}{c}\text { Tasting } \\
\text { Room }\end{array}$ & Wine Club \\
\hline 2013 Accession case sales & 1625 & 1625 & 1300 & 1950 \\
\hline \% of total cases produced & $25 \%$ & $20 \%$ & $30 \%$ & $25 \%$ \\
\hline Case price received (USD/case) & 330 & 330 & 660 & 528 \\
\hline Price to consumers (USD/bottle) & 110 & 55 & 55 & 44 \\
\hline Revenue (USD) & 536,250 & 536,250 & 858,000 & $1,029,600$ \\
\hline \% of total Accession revenue & $18 \%$ & $18 \%$ & $29 \%$ & $35 \%$ \\
\hline
\end{tabular}

Source: ARA Estates Winery

(A case of wine to consists of $12750 \mathrm{ml}$ bottles)

Many of ARA Estates' established customers had personal relationships with winery personnel. They enjoyed the older, more historic Napa Valley wines that were often lower in alcohol and more balanced in style, both of which were stylistically common characteristics among mountain-focused producers. Getting this particular group dialed into the wine club would ensure their continued support without requiring them to travel to the tasting room for purchases. Additionally, getting this population of consumers on board with the price evolution would be an essential part of making the brand restructuring a financial success.

\footnotetext{
${ }^{8}$ The term "Michelin-star" is a symbol of fine dining quality and is based entirely on a staff of anonymous reviewers. Awards range from 0 to 3 stars and are based on quality, mastery of technique, personality, and consistency of the food.
} 
In addition to retaining existing club memberships and encouraging new enrollment from longstanding customers, Ethan hoped to gain the following of the young professional crowd. Ethan commented, "The young professionals tend to buy wine at new and trendy restaurants on both the East and West Coasts. Establishing a desirable location on the restaurant wine lists will be imperative for introducing ARA Estates to the next generation of wine consumers. I would like to continue to target these sophisticated, farm-to-table fine-dining restaurants.” Ethan hoped that with the changes he was proposing, Accession would be moved to a more prominent position on restaurant wine lists, introducing ARA Estates Winery to a new customer base that would not have preconceived pricing expectations. In addition, greater prominence on wine lists and exposure to this demographic could act as a gateway for some of the other mountain specific labels in the ARA portfolio and potentially lead to additional wine club enrollment.

\section{Changes on the Horizon}

Ethan took the increases in competitor prices as an indicator that it was time to make a move with the Accession label. In addition, Accession's popularity plus the need for capital in order to move toward an entirely estate grown fruit-by purchasing vineyards-prompted Ethan to consider increasing the price point for Accession to USD 75/bottle beginning with the release of the 2013 vintage (scheduled for 2016) and to USD 90/bottle with the release of the 2015 vintage in spring 2018. There were few companies, mostly international, that supplied the decorative foil capsules for the top of the wine bottle and other packaging materials. Often, orders took over a year to complete and could be held up at customs. With these pressures on his mind, in 2014, Ethan ordered the new packaging material for the Accession label. The use of the upscale packaging was meant to coincide with the price increase for the 2013 vintage, scheduled for bottling in early 2015 and release in 2016. However, the 2011 vintage (released in spring 2013) had slow sales due to the difficult growing conditions and lower quality. Despite a good growing season in 2012, the 2011 challenges had made moving the 2012 vintage slower than normal. They were lucky in 2013 as it was considered an excellent growing season with superb wines.

Generally, production levels decreased slightly when wineries switched from grower-contracted fruit to estate owned vineyards because there was a time investment in redeveloping or retraining newly purchased property to meet estate standards. The increased cost associated with packaging changes and the acquisition of new vineyard property would typically translate to increased overhead costs for a winery, at least in the short-term. In this case, however, Ethan was relieved to find that the cost to switch to estate-grown fruit and new packaging would be offset by the increase in the price per bottle and by not paying an outside grower for non-estate fruit; however, reduction in total cases available at the national level remained a concern.

Andrew Anderson was concerned with Ethan's plan to reduce Accession production and increase the price simultaneously. Andrew had continually improved winery practices and wine quality since his hiring and worked collaboratively with Ethan to evolve the ARA Estates brand. Andrew felt this would result in an undesirable increase in cases of the mountain specific labels 
and would move ARA Estates from a tiered pricing brand to a high-end exclusive producer, essentially eliminating the younger and less financially wealthy clientele. If Ethan moved forward with his plan to increase the price of Accession, Andrew argued that the risk for ARA Estates would be that its "entry level” Cabernet would be significantly more expensive than other similar producers, and this would result in a loss of sales. He, Ethan, and Paul had engaged in multiple discussions. Andrew did not know the customer as well as Paul, who felt the change would work, but Andrew knew the wine business and changing the brand image could harm the winery beyond repair and alienate current customers. Paul tried to assure him that consumers would still see value at the new price considering the quality of the wine being produced.

\section{GOING FORWARD}

\section{The Decision}

Ethan had the Accession label redesigned and printed (see Exhibit 6), ordered upgraded capsules, and talked to distributors about the coming price increase for the 2013 vintage. However, he was questioning these decisions, especially because of Andrew's continuing concerns and warnings. Still, the distributors were confident, and Ethan knew that distributor buy-in was rare for a price increase and critical to success. However, to maintain the revenue targets with the drop in production, DTC sales would have to make up an even larger portion of case sales. Increasing DTC sales while decreasing production would result in tighter allocations for distributors and contribute to even higher exclusivity. 


\section{Exhibit 6}

Accession Label Before (left) and After (right) the Redesign
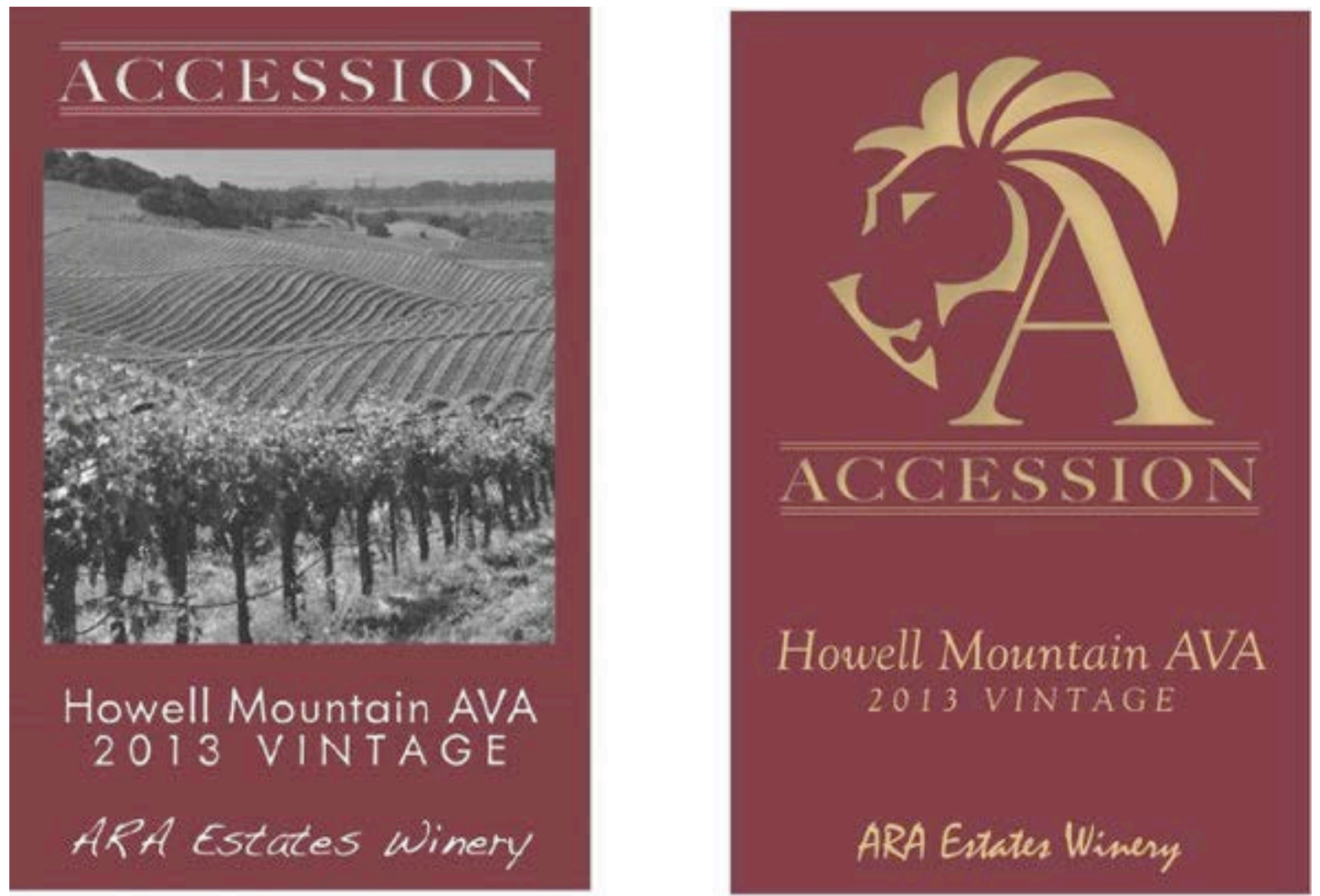

Source: Case authors

The margins on DTC sales were very desirable to Ethan. Selling a case of Accession through the tasting room resulted in USD 660, compared to just USD 330 per case sold through distributors to retail and restaurant outlets. While the price difference was significant, selling through distributors allowed the brand to reach major markets throughout the country and had the potential to extend the brand's reputation further than DTC sales. The production costs for the 2013 Accession were estimated to be USD 300/case. However, additional costs were associated with selling DTC, including Paul Teel's salary, costs of maintaining the tasting room space, marketing to consumers, and the cost of the wine poured in the tasting room. Shipping was paid for by the purchaser or distributor of the wine.

As he went through his mental checklist, Ethan thought,

Another factor that is weighing on my mind is what the reviews will be for the 2013 vintage. If the 2013 Accession is reviewed at a 96 or 97 following its release, I'm confident that it will be enough to pull the brand through the price increase. Although everyone in ARA Estates' sales and production team thinks the 2013 vintage is good enough to get scored in the 96 to 97 range, at this point it is out of our hands. Plus, the reviews don't come out until after the wine's release. The 
result could have a huge impact on the success of this pricing strategy. What if I implement the price increase, and we receive a low score... How will I manage my way out of that one?

Ethan needed to make a final decision on price,

Should I stay with the plan to increase Accession to USD 75/bottle (with plans to go up to USD 90/bottle with the 2015 vintage) for the 4,000 cases, back down to a lower price increase, or keep Accession at the current price point?

And that decision, he knew, would dictate other decisions concerning ARA Estates' distribution and promotion strategies. Perhaps he should consider creating a new line of wine as the premium brand for the winery without risking Accession's loyal following.

\section{Time Was Running Out}

Ethan pulled his car into the winery's parking lot and was pleased with the bustle of preparations underway for the spring release party. He thought,

I know that if I move forward with the price increase, I have to communicate and 'sell' the change to wine club members, not to mention that I need some level of buy-in from Andrew. This is my chance to start the marketing campaign representing Accession's new positioning. But, can I pull it off?

As he shut the door of his car and looked from his perch on Howell Mountain over the Napa Valley, he made up his mind. 


\section{Appendix 1 ARA Estates Winery Timeline}

1980 Shawn Lincoln arrived in Napa Valley/Howell Mountain District

1990 ARA Estates founded by Shawn Lincoln

19923,500 cases of the 1990 Accession released at USD 35/bottle

Grapes sourced from Amador and Central Coast areas

2004 Financial trouble from poor marketing and a lack of stylistic focus

Shawn retired; Ethan Dorsey and Andrew Anderson hired

2005 Ethan pulls non-Napa production from distribution, Accession increased to USD 40 at 3,500 cases (2002 vintage)

2006 Consulting winemaker hired, decision made to focus ARA Estates Winery’s production on mountain wines

2007 Premium vineyard contracts in place Mountain wines being produced included Veeder, Howell, and Spring Mountain AVAs

Ethan evolves winery to a true business model and makes several hires:

National Sales Director, Controller, Director of Wine Club (Paul Teel), and Retail Sales Director

2008 Sales expanded from tasting room only to restaurants and wine club

2009 Accession first reviews of the 2006 vintage released at 94 points Accession was released at USD 40/bottle (2006 vintage)

2010 ARA Estates actively pursues the purchase of mountain vineyard properties Accession released at USD 50/bottle (2007 vintage)

Accession gains in popularity and scores 97 points (2007 vintage)

2011 Poor weather during the growing season results in quality issues Accession price increased to USD 55/bottle

2012 Accession (2008) poured by the glass at the French Laundry Accession case production up to 6,500 (2009 vintage)

2014 Napa Valley wines experienced a 3.4 percent increase in sales volume (generally 2012 vintages), Cabernet Sauvignon prices at USD 88.45 and Napa Valley reds priced at USD 77.91 Ethan planned to increase prices for the 2013 Accession, new packaging for Accession labeled ordered, slow 2011 vintage movement due to quality

Acquisition of a small mountain vineyard for ARA's super premium wines

2015 Slow 2012 vintage movement due to backlog of the 2011 vintage

20164,000 cases of the 2013 vintage planned to be released at $\$ 75 /$ bottle

2018 intage planned to be released at $\$ 90 /$ bottle 